\title{
Effect of Variety and Size of Stem Cutting on Flesh Root Yield and Yield Components of Sweet Potato
}

\author{
Musyimi Benjamin Muli and Dau Mwakina \\ Kenya Agricultural and Livestock Research Organization, Industrial Crops Research Institute, P.O. Box 16 Mtwapa, 80109, Kenya
}

\begin{abstract}
Sweet potato is an important food crop which contributes to food security. Storage roots are stored in the ground and harvested when needed. In coastal Kenya, the production of the crop is limited by lack of adaptable varieties and shortage of planting materials at the onset of long rains. The prevailing prices of sweet potato vines for planting present a hindrance for sweet potato cultivation culminating to low acreages by farmers. This study was carried out during the long rains of 2011 to 2013 to determine the effect of variety and size of sweet potato cutting on root yield. Four sweet potato varieties were planted under four stem cutting sizes of four, six, eight and 10 nodes. The four varieties were K135, Bungoma, SPK004 and Mtwapa 8 (check). The experimental design was a split plot with varieties assigned to main plots and cutting sizes to sub-plots. The number of roots per plant for Bungoma variety was significantly $(P \leq 0.05)$ less than that for the check, and variety K135 showed significantly $(P \leq 0.05)$ higher number of marketable root per plant than the check. The same trend was observed for root yield per hectare. The check variety had the highest percent of dry matter and was significantly higher than that of SPK004 and Bungoma varieties. There were no significant $(P \leq 0.05)$ differences among the stem cutting sizes as regards to number of roots per plant, number of marketable root per plant and percent of dry matter. The cutting size of six nodes gave similar root yield as the recommended eight nodes, and therefore farmers can adopt shorter vines than the recommended, hence saving on the cost of planting materials.
\end{abstract}

Key words: Cutting size, sweet potato, variety, root yield, vine yield, dry matter.

\section{Introduction}

Sweet potato (Ipomoea batatas L.) is a vital staple food for the world's neediest people. It is cultivated in 100 developing countries and is one of the five most important crops in more than 50 counties. In Africa, sweet potato is among the most important food crops in countries surrounding Lake Victoria. In Kenya, the crop is important in Nyanza, Western and Coast provinces.

Sweet potato is the second most important root crop after cassava in the coastal region of Kenya. It is grown mainly by smallholder female farmers for subsistence and male farmers for cash. The crop plays an important role in household food security [1]. Sweet potato is adapted to many agro-ecological zones (AEZs) and can yield well with few inputs [2]. Sweet potato yield depends on management systems,

Corresponding author: Musyimi Benjamin Muli, M.Sc., research field: food crops agronomy. environmental conditions and variety. The average root yield in the region is about 8 ton/ha [3]. Muli and Agili [4] reported sweet potato yield ranging from 10.5 ton/ha to 40.2 ton/ha due to differences in variety and time of harvesting.

Significant sweet potato yield differences due to variety and environmental conditions have been reported in studies carried out in Kenya and other parts of the world [5-7]. The varietal and environmental responses are attributed to differences in pest and disease attack, soil fertility, management practices, genetic variability and rainfall. Most sweet potato varieties produced in coastal Kenya are local landraces that are adaptable to the local growing conditions, but are low yielding and susceptible to sweet potato weevils and feathery mottle virus.

The acreage under sweet potato in the region is low, and this has been attributed to inadequate supply and the resulting high cost of planting materials. The current price of two shilling per cutting translates to 
KES 26,000.00 (1 USD to 103.6 KES) per acre, and this leads to many farmers planting very small acreages. It is hypothesized that if shorter cuttings are used, this cost of planting materials can be lowered, hence enabling the farmers to increase the acreage under the crop. It was therefore important to carry out an experiment to find out how the size of the cutting affects the sweet potato storage root yield. Therefore, the objectives of the study were to determine the effect of reducing the size of stem cutting below the recommended size on the flesh root yield of sweet potato, and to determine whether the optimum size depends on variety used.

\section{Materials and Methods}

The study was carried out at the Kenya Agricultural and Livestock Research Organization's Research Centre at Mtwapa during the long rain seasons of 2011 to 2013. The study site has an altitude of $15 \mathrm{~m}$ above sea level and is in the agro-ecological zone described as the coastal lowland 3 (CL3) [8]. The soils at the site are loamy sands with $\mathrm{pH}$ 6.9. They are deficient in macro-nutrients, especially nitrogen [9] and have low organic matter content and cation exchange capacity [10]. The mean annual rainfall for the site is $1,200 \mathrm{~mm}$, with about $75 \%$ of it falling during the long rain season. The mean monthly minimum and maximum temperatures are about $22{ }^{\circ} \mathrm{C}$ and $30^{\circ} \mathrm{C}$, respectively.

Three sweet potato varieties were evaluated alongside one local check under four stem cutting sizes. The three varieties were Bungoma, SPK 004 and K135. Sweet potato variety Mtwapa 8 was used as the local check. The four stem cutting sizes comprised of S4, S6, S8 and S10, representing four, six, eight and 10 nodes, respectively (Fig. 1). The stem cutting size of S8 was used as a check.

The experimental design was a split plot with varieties assigned to main plots and cutting sizes to sub-plots. The treatments were replicated three times. Ridges were spaced at $1 \mathrm{~m}$ apart and plots consisted of four ridges of $6 \mathrm{~m}$ long. Planting was done on the ridges, and for each respective size of stem cutting, three nodes were buried and the rest were exposed. The

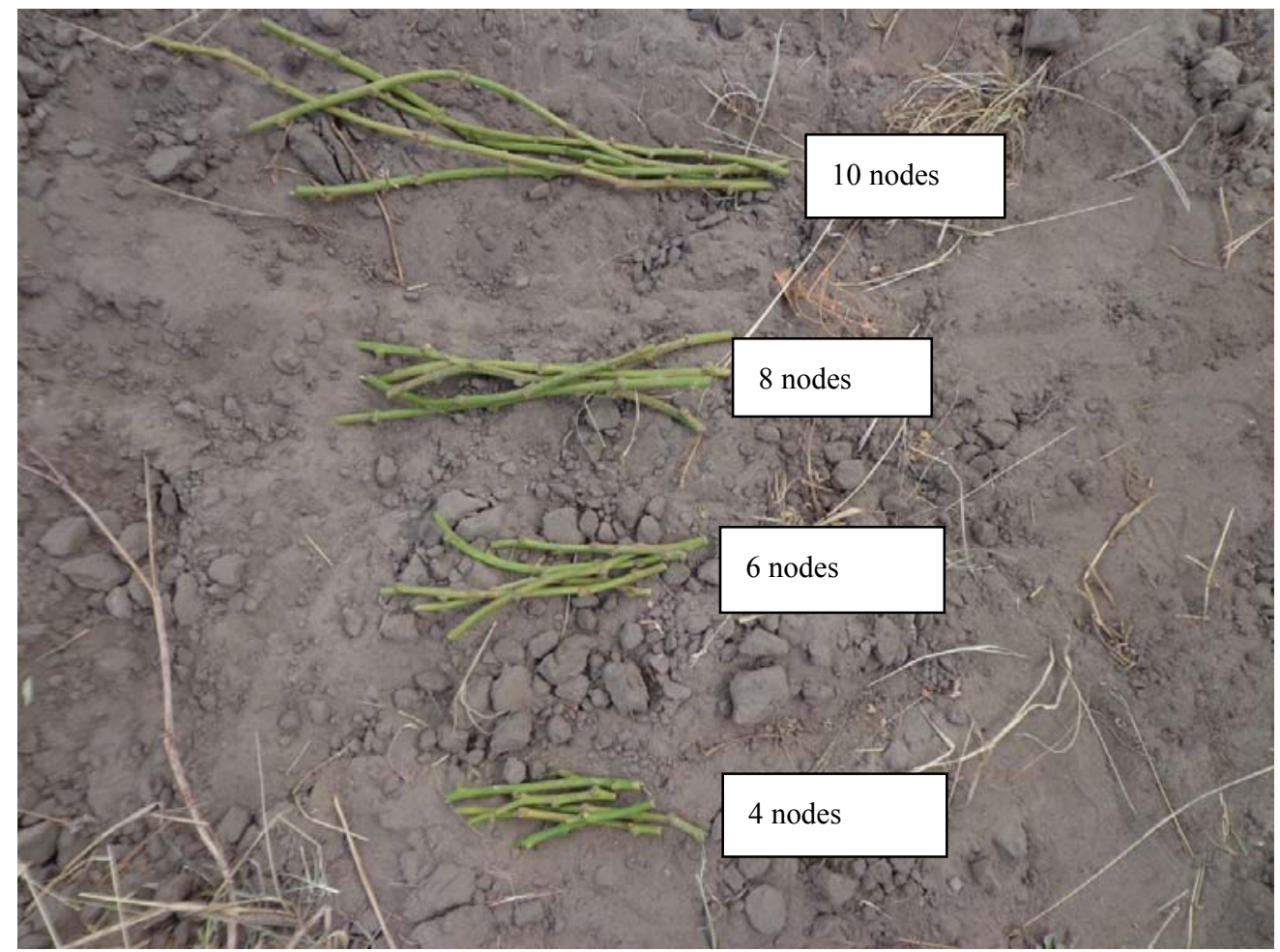

Fig. 1 Stem cutting sizes for Mtwapa 8 (check). 
intra-row spacing was $30 \mathrm{~cm}$. Compound fertilizer NPK 17:17:17 was applied at the rate of $100 \mathrm{~kg} / \mathrm{ha}$. To control the sweet potato weevil, "Buddock" 025 EC (an emulsifiable concentrate containing $25 \mathrm{~g} / \mathrm{L}$ beta cyfluthrin) was sprayed during the second month of growth. Earthing was done to complement the chemical control when the ground started to crack as a result of the growing storage roots underneath. The crop was weeded three times throughout its cycle. The following data were collected on: percent of sprouting, number of storage roots per plant, number of marketable roots per plant, percentage of marketable roots per plant, storage root yield per hectare, vine yield per hectare and percent of dry matter.

\section{Results}

Initial analysis revealed significant $(P<0.05)$ differences among varieties as regards the number of plants harvested per plot, probably as a result of differences in percent of sprouting. This called for the parameter (number of plants harvested) to be treated as a covariate to adjust for the differences in stand count. The results also showed that there was no significant $(P<0.05)$ interaction between the varieties and stem cutting lengths and therefore results are presented separately.

The results on the performance of sweet potato varieties as regards yield and yield components are shown in Table 1. Percent of sprouting depended on the variety, and all the test varieties showed significantly $(P<0.05)$ higher percentage than the check. Variety SPK004 also recorded significantly higher sprouting percentage than variety K135. The number of storage roots per plant was significantly $(P$ $<0.05)$ lower for Bungoma variety than all the other varieties including the check. As regards the number of marketable roots per plant, significant $(P<0.05)$ differences were only observed for varieties Bungoma and K135. Variety K135 indicated the highest number of marketable roots per plant (2.2), which was significantly $(P<0.05)$ higher than for all other varieties except variety Bungoma. There were no significant $(P<0.05)$ differences observed between the check and the rest of the varieties as regards this parameter. Storage root yield per hectare ranged from 13.6 ton/ha to 18.3 ton/ha for Bungoma and K135, respectively. There was no significant $(P<0.05)$ yield difference between test varieties and the check. However, variety K135 yielded significantly $(P<0.05)$ higher than both Bungoma and SPK004. The same observation was made for sweet potato vine yield with an exception of Bungoma which did not exhibit any significant differences with $\mathrm{K} 135$, as is the case with storage root yield. Mtwapa 8 (check) showed significantly $(P<0.05)$ higher percent dry matter than all the test varieties except K135.

Table 2 shows the effect of stem cutting length on yield and yield components of sweet potato varieties. Percent of sprouting increased with the increase in length. S4 and S6 showed significantly $(P<0.05)$ lower sprouting percentage than the check. The length of 10 nodes $(\mathrm{S} 10)$ indicated significantly $(P<0.05)$ higher number of storage roots per plant than the check, but not S6. As regards the number of marketable roots

Table 1 Performance of sweet potato varieties.

\begin{tabular}{llllllll}
\hline \multirow{2}{*}{ Variety } & \multicolumn{7}{c}{ Parameters } \\
\cline { 2 - 8 } & $\begin{array}{l}\text { Percent of } \\
\text { sprouting } \\
(\%)\end{array}$ & $\begin{array}{l}\text { No. of storage } \\
\text { roots per plant }\end{array}$ & $\begin{array}{l}\text { No. of marketable } \\
\text { roots per plant }\end{array}$ & $\begin{array}{l}\text { Percent of } \\
\text { marketable roots per yield } \\
\text { plant (\%) } \\
\text { (ton/ha) }\end{array}$ & $\begin{array}{l}\text { Vine yield } \\
\text { (ton/ha) }\end{array}$ & $\begin{array}{l}\text { Percent of dry } \\
\text { matter (\%) }\end{array}$ \\
\hline SPK004 & $97.8^{\mathrm{a}}$ & $3.0^{\mathrm{a}}$ & $1.7^{\mathrm{ab}}$ & $56.6^{\mathrm{c}}$ & $14.5^{\mathrm{b}}$ & $11.9^{\mathrm{b}}$ & $34.9^{\mathrm{bc}}$ \\
Bungoma & $97.6^{\mathrm{ab}}$ & $1.9^{\mathrm{b}}$ & $1.3^{\mathrm{b}}$ & $66.4^{\mathrm{ab}}$ & $13.6^{\mathrm{b}}$ & $16.1^{\mathrm{ab}}$ & $34.3^{\mathrm{c}}$ \\
K135 & $97.4^{\mathrm{b}}$ & $3.0^{\mathrm{a}}$ & $2.2^{\mathrm{a}}$ & $71.6^{\mathrm{a}}$ & $18.3^{\mathrm{a}}$ & $18.3^{\mathrm{a}}$ & $35.8^{\mathrm{ab}}$ \\
Mtwapa 8 & $94.2^{\mathrm{c}}$ & $3.2^{\mathrm{a}}$ & $1.8^{\mathrm{ab}}$ & $58.1^{\mathrm{bc}}$ & $15.8^{\mathrm{ab}}$ & $15.2^{\mathrm{ab}}$ & $36.7^{\mathrm{a}}$ \\
\hline LSD & 0.24 & 0.74 & 0.54 & 9.32 & 3.16 & 6.13 & 1.01 \\
\hline
\end{tabular}

${ }^{\mathrm{a}-\mathrm{c}}$ Means followed by the same superscript are not significantly different $(P \leq 0.05)$. LSD: least significant difference. 
Table 2 Effect of stem cutting length on yield and yield components of sweet potato varieties.

\begin{tabular}{llllllll}
\hline \multirow{2}{*}{ Size } & \multicolumn{7}{c}{ Parameters } \\
\cline { 2 - 8 } & $\begin{array}{l}\text { Percent of } \\
\text { sprouting (\%) }\end{array}$ & $\begin{array}{l}\text { No. of storage } \\
\text { roots per plant }\end{array}$ & $\begin{array}{l}\text { No. of marketable } \\
\text { roots per plant }\end{array}$ & $\begin{array}{l}\text { Percent of marketable } \\
\text { roots per plant (\%) }\end{array}$ & $\begin{array}{l}\text { Storage root } \\
\text { yield (ton/ha) }\end{array}$ & $\begin{array}{l}\text { Vine yield } \\
\text { (ton/ha) }\end{array}$ & $\begin{array}{l}\text { Percent of dry } \\
\text { matter (\%) }\end{array}$ \\
\hline S10 & $98.5^{\mathrm{a}}$ & $3.2^{\mathrm{a}}$ & $1.9^{\mathrm{a}}$ & $60.8^{\mathrm{a}}$ & $17.2^{\mathrm{a}}$ & $16.9^{\mathrm{a}}$ & $35.3^{\mathrm{a}}$ \\
S8 & $98.4^{\mathrm{a}}$ & $2.6^{\mathrm{b}}$ & $1.6^{\mathrm{a}}$ & $63.3^{\mathrm{a}}$ & $16.2^{\mathrm{a}}$ & $17.4^{\mathrm{a}}$ & $35.7^{\mathrm{a}}$ \\
$\mathrm{S} 6$ & $97.0^{\mathrm{b}}$ & $2.8^{\mathrm{ab}}$ & $1.6^{\mathrm{a}}$ & $62.0^{\mathrm{a}}$ & $16.0^{\mathrm{a}}$ & $14.4^{\mathrm{b}}$ & $35.2^{\mathrm{a}}$ \\
S4 & $93.0^{\mathrm{c}}$ & $2.4^{\mathrm{b}}$ & $1.6^{\mathrm{a}}$ & $67.5^{\mathrm{a}}$ & $12.4^{\mathrm{b}}$ & $13.8^{\mathrm{b}}$ & $35.5^{\mathrm{a}}$ \\
\hline LSD & 0.23 & 0.51 & 0.51 & 7.78 & 1.49 & 2.43 & 1.57 \\
\hline
\end{tabular}

${ }^{\mathrm{a}, \mathrm{b}}$ Means followed by the same superscript are not significantly different $(P \leq 0.05)$. LSD: least significant difference.

per plant, percent of marketable roots per plant and percent of dry matter, the length of stem cutting did not seem to have any influence. However, the length of four nodes (S4) showed significantly $(P<0.05)$ lower storage root yield than the rest of treatments including the check. The same observation was made for sweet potato vine yield with an exception of S6, which did not show any significant $(P<0.05)$ difference with S4.

\section{Discussion}

Percent of sprouting depended on variety, and differences were attributed to differences in sizes of internodes among the varieties. Longer vines result in wastage of planting material, while shorter ones establish more slowly and give poorer yields [11]. Mtwapa 8 had the shortest internodes and SPK004 had the longest. This implied that for Mtwapa 8, very small portion was left exposed after burring the three nodes, and the exposed portion was liable to desiccation due to environmental conditions depending on its size. The number of roots per plant is a varietal characteristic, and it is expected that less adapted variety, like Bungoma, should have the least number of roots per plant. The same applies to the number of marketable roots per plant. SPK004 was among the varieties with the highest number of roots per plant, however, most of its storage root were too small to be regarded as marketable and this is the reason why the variety had the lowest percent of marketable roots per plant. Bungoma variety is new and less adapted to the region and this is the reason for the lowest yield among the other varieties. Sweet potato vine yield depends on vegetative ability of the variety and SPK has long and slender stems with very small pointed leaves hence less biomass. The percent of dry matter range of $34.3 \%$ to $36.7 \%$ is within the range reported by Mtunda et al. [12].

The sprouting percentage increased with the increase in size of the cutting. This was expected because the shorter the cutting, the shorter is the portion exposed to sun rays and hence liable to drying leading to failure to sprout. The size of stem cutting was also found to have an influence in number of roots per plant with longer stem cutting having the highest number of roots per plant. This could be due to longer cutting becoming vegetative earlier and commencing the process of yield formation earlier. Storage root yield was found to increase with the increase in cutting size. This observation is similar to that reported by Godfrey-Sam-Aggrey [13], though his work was based on longer cuttings than that used in this study. The same results were also reported by Wilson [14], where the length of the cutting depended on the size of the internodes. In addition to size of the cutting, the flesh root yield is also reported to vary with the portion of the cutting [14], either base, middle or the tip. The same explanation can also be extended to sweet potato vine yield, since vegetative growth will be affected by the time of leaf formation commences. The percent of dry matter was not influenced by the cutting size, and this was expected since the parameter is a function of variety. 


\section{Conclusions and Recommendations}

The study results show that variety K135 is comparable to Mtwapa 8 in terms of yield and percent of dry matter. The stem cutting size of six nodes gave the same yield as the recommended size of eight nodes, and if adopted, farmers will be able to reduce the cost of planting materials. So, variety K135 should be promoted for adoption by farmers alongside with stem cutting size of six nodes.

\section{Acknowledgments}

The authors wish to acknowledge the financial assistance provided by the director Kenya Agricultural Research Institute (KARI) through Kenya Agricultural Productivity and Agribusiness Project. They also thank the centre director of KARI, Mtwapa for provision of facilities, as well as Mr. Charles Chiro participation in trial management and data collection.

\section{References}

[1] Ndolo, P. J., Mcharo, T., Carey, E. E., Gichuki, S. T., Ndinya, C., and Maling'a, J. 2001. "Participatory On-Farm Selection of Sweet Potato Varieties in Western Kenya." African Crop Science Journal 9 (1): 41-8.

[2] Kipkorir, N. 2016. "Sweet Potato Production in Kenya." Accessed April 14, 2016. http://nicklykipkorir.blogspot.co.ke/2016/04/sweet-potato -production-in-kenya.html.

[3] Ministry of Agriculture. 2012. Ministry of Agriculture Annual Report.

[4] Muli, M. B., and Agili, S. 2013. "The Influence of Genotype and Harvesting Regime on Yield of Orange-Fleshed Sweet Potatoes and Their Ranking by Farmers in Coastal Kenya." East African Agriculture and
Forestry Journal 79 (2): 81-5.

[5] Nderitu, J., Sila, M., Nyamasyo, G., and Kasina, M. 2009. "Insect Species Associated with Sweet Potatoes (Ipomoea batatas (L.) Lamk) in Eastern Kenya." Int. J. Sustain. Crop Prod. 4 (1): 14-8.

[6] Endale, G., and Gebremedhin, W. G. 2001. "Effect of Spatial Arrangement on Tuber Yield of Some Potato Cultivars." African Crop Science Journal 9 (1): 67-76.

[7] Egbe, O. M. 2012. "Relative Performance of Three Sweet Potato Varieties in Sole and Intercrop Systems in Southern Guinea Savanna Ecology of Nigeria." Global J. Sci. Front. Res. Agri. Biol. 12 (3): 37-43.

[8] Jaetzold, R., and Schmidt, H. 2006. "Coast Province.” In Farm Management Handbook of Kenya: Natural Conditions and Farm Management Information. Vol. 2. Kenya: Ministry of Agriculture.

[9] Ramadhan, A., Kiura, J. N., and Njunie, M. N. 2008. "Dairy Production in Coastal Kenya: The Current Status." Presented at the 11 KARI Biennial Conference at KARI Headquarters, November 10-14, 2008.

[10] Kenya Agricultural Research Institute (KARI). 1994. Fertilizer Use Recommendations: Coastal Districts (Kilifi, Kwale and Lamu). Nairobi, Kenya: KARI.

[11] Kaundo, H. O. 2016. "Complete Guide on Sweet Potato Farming in Kenya." Accessed December 1, 2016. http://www.farmerstrend.co.ke/complete-guide-sweet-pot ato-farming-kenya/.

[12] Mtunda, K. J., Msolla, S. N., Muhanna, M., Ngereza, A., Masumba, E., and Larsen, A. 2004. "Evaluation of Sweet Potato for Early Maturity in the Eastern Agro-Ecological Zone of Tanzania." In Proceedings of the 9th ISTRC-AB Triennial Symposium, 443-7.

[13] Godfrey-Sam-Aggrey, W. 2008. "Effect of Cutting Lengths on Sweet Potato Yield in Sierra Leone.” Journal of Experimental Agriculture 10 (1): 33-7.

[14] Wilson, L. E. 1988. "Sweet Potato (Ipomoea batatas) Planting Material." Institute for Research, Extension and Training in Agriculture (IRETA) Publications No. 2/88. Accessed August, 1988. https://www.ctahr.hawaii.edu/adap/ Publications/Ireta_pubs/sweet_planting.pdf. 